\title{
E-RETAIL PERCETAKAN ANAMBALEH DESAIN MENGGUNAKAN FRAMEWORK LARAVEL
}

\author{
Dony Novaliendry ${ }^{1}$, Viony Dwiyana Puteri ${ }^{2 *}$ \\ ${ }_{1}^{1}$ Program Studi Pendidikan Teknik Informatika, Universitas Negeri Padang, Indonesia \\ ${ }^{2}$ Program Studi Pendidikan Teknik Elektronika, Universitas Negeri Padang, Indonesia \\ Jl. Prof. Hamka Kampus UNP Air Tawar Padang \\ *Corresponding Author: vionyd@gmail.com
}

\begin{abstract}
ABSTRAK
E-retail adalah sarana bagi pemilik usaha percetakan untuk mempromosikan produk dan jasa yang diberikan, serta dapat menjadi sarana untuk mendapatkan informasi tentang produk-produk percetakan bagi customer. Keterbatasan tentang informasi produk serta keterbatasan dalam menjangkau customer dan lamanya proses pemesanan produk menjadi kendala bagi percetakan dalam memasarkan produknya. Tujuan dari penelitian ini adalah membuat e-retail yang menggunakan teknik MVC (Model View Controller), yang bisa diakses secara online. Metode MVC digunakan untuk membuat e-retail dengan menggunakan framework Laravel. Pengelolaan database menggunakan MySQL. Penelitian ini menghasilkan E-retail berbasis web yang dapat memberikan informasi secara real-time, mengelola data produk dan transaksi serta dapat menjadi sarana promosi bagi percetakan. Sehingga jangkauan customer lebih luas, dapat menjadi sarana untuk mendapatkan infomrasi bagi customer, serta pengelolaan data dapat dilakukan secara online. Sehingga pemilik percetakan dapat mengelola tokonya memalui media web.
\end{abstract}

Kata Kunci: E-Retail, Percetakan, Website Penjualan, Framework, Laravel.

\begin{abstract}
E-Retail is a means for printing business owners to promote the products and services provided, and can be a means to get information about printing products for customers. Limitations on product information and limitations in reaching customers and the length of the product ordering process becomes an obstacle for printing in marketing its products. The purpose of this research is to create e-retail using MVC (Model View Controller) technique, which can be accessed online. The MVC method is used to create e-retail by using a Laravel framework. Database management using MySQL. This research generates a Web-based E-retail that can provide information in real-time, manage product data and transactions and can be a means of promotion for printing. So that the customer reach wider, can be a means to obtain information for the customer, as well as the management of data can be done online. So that the printing owner can manage the store web media.
\end{abstract}

Keywords: E-Retail, Printing, Sales Website, Framework, Laravel.

JTIP@Attribution-ShareAlike 4.0 International License

\section{PENDAHULUAN}

E-retail merupakan sistem jual beli barang atau jasa secara eceran dengan metode B2C (Business to Customer) melalui media elektronik atau online. Dengan perkembangan teknologi customer tidak harus datang langsung ke toko untuk memesan produk-produk percetakan. E-retail adalah penjualan barang dan jasa melalui media internet atau saluran elektronik lainnya, untuk penggunaan pribadi atau rumah tangga oleh konsumen, yang mencakup semua kegiatan B2C (Business to Customer) [1]. Electronic retailing adalah retailing yang diselenggarakan secara online dengan internet untuk keperluan toko eceran. Pihak yang melakukan kegiatan retail atau e-tailing ini disebut e-retailer. Bisnis e-tailing adalah termasuk tipe bisnis B2C (Business to Customer) yaitu transaksi online yang terjadi antara perusahaan dan konsumen individu[2].

Anambaleh Desain adalah usaha dibidang percetakan. Percetakan adalah sebuah bidang usaha yang berhubungan dengan proses cetak mencetak baik secara manual maupun digital[3]. Produkproduk Anambaleh Desain yaitu berbagai jenis sablon, salempang, pin, gantungan kunci, dan lainlain. Proses pemesanan produk-produk percetakan 
dilakukan secara konvensional yaitu dengan cara customer datang langsung ke toko dan memesan produk yang diinginkan lalu menjemput kembali setelah pesanan selesai. Cara ini menimbulkan beberapa masalah yaitu customer terbatas hanya pada wilayah di sekitar percetakan, customer harus bolak-balik ke toko untuk memesan dan menjemput pesanannya, terjadinya kesalahan dalam pencatatan dan penghitungan, serta sulitnya proses mengolah, menyimpan dan berbagi data dan informasi.

Berdasarkan masalah-masalah yang dihadapi oleh Anambaleh Desain yang salah satu diantaranya adalah kesulitan dalam mengolah, menyimpan dan berbagi data. DBMS (Database Management System) dapat dijadikan alternatif dalam penyimpanan data. Data yang tersimpan pada DBMS dapat diolah menjadi informasi dengan cara mengkoneksikannya melalui baris-baris kode pada website yang dibangun dengan menggunakan bahasa pemrograman PHP dan Framework Laravel yang penulis gunakan. Laravel adalah framework PHP yang menekankan fleksibelitas dan kesederhanaan dalam desainnya[4].

Untuk menampung basis data dalam jumlah kecil dapat digunakan MySQL sebagai DBMS. MySQL adalah software sistem manajemen basis data SQL multi user dan DBMD Multithread, MySQL berasal dari SQL (Structured Query Language) [5]. MySQL adalah DBMS (Database Management System) yang menggunakan perintah dasar SQL (Structured Query Language)[6]. MySQL adalah DBMS (Database Management System) multi user dan multithread yang menggunakan perintah dasar SQL (Structured Query Language). Bahasa pemrograman PHP memiliki banyak framework. Framework yang paling banyak digunakan pada bahasa pemrograman PHP adalah framework Laravel. Laravel adalah salah satu framework PHP yang dikembangkan oleh Taylor Ottwel yang bersifat open source[7].

\section{METODE}

E-retail Anambaleh Desain menggunakan metode MVC (Model-View-Controller). MVC merupakan sebuah metode untuk membuat aplikasi dengan cara memisahkan Model dari View dan cara bagaimana memprosesnya melaui Controller[8]. MVC adalah sebuah metode dalam pemrograman yang memisahkan komponen utama dalam membangun aplikasi yaitu, manipulasi data, tampilan atau user interface, dan mengontrol aplikasi[9].

MVC adalah sebuah metode yang memishakan komponen model yang berfungsi untuk pengolahan data, view yang berfungsi untuk tampilan serta controller yag berfungsi sebagai pemrosesan dan logic program.

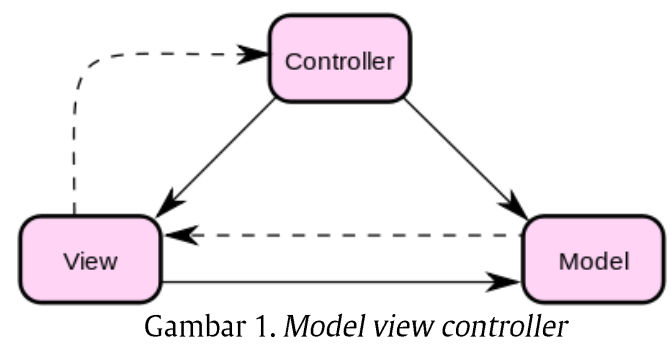

Model merupakan komponen yang berhubungan dengan database. Pada komponen ini biasanya dilakukan proses CRUD (Create Read Update Delete ), search data dan select data. View adalah komponen yang berhubungan dengan user interface atau tampilan halaman yang digunakan oleh end-user. View bertugas untuk menampilkan data dari pemrosesan yang dilakukan oleh model dan controller. Sedangkan controller berperan sebagai jembatan penghubung.

\section{Analisis dan Perancangan Sistem}

Analisis dan perancangan sistem adalah suatu proses memahami dan menspesifikasikan secara rinci proses bisnis, permasalahan, penyebab masalah, serta merencankan sistem yang dapat menyelesaikan permasalahan-permasalahan yang ada.

\section{Analisis Aturan Bisnis}

Bertujuan untuk menggambarkan bagaimana aturan setiap proses yang dilakukan pada sistem.

Tabel 1. Analisis Aturan Bisnis

\begin{tabular}{lll}
\hline No & Proses & Aturan \\
\hline 1 & Pemesanan & $\begin{array}{l}\text { Customer mendapatkan bukti } \\
\text { pemesanan setelah menyepakati harga } \\
\text { dan desain yang diinginkan dengan } \\
\text { customer service. }\end{array}$ \\
\hline \multirow{2}{*}{ Produksi } & $\begin{array}{l}\text { Bagian produksi memulai proses } \\
\text { produksi setelah customer service } \\
\text { memberikan catatan desain yang } \\
\text { diinginkan customer. }\end{array}$ \\
\hline 3 & Pembayaran & $\begin{array}{l}\text { Customer akan mendapatkan kwitansi } \\
\text { setelah melakukan pembayaran dan } \\
\text { menerima pesanan. }\end{array}$ \\
\hline
\end{tabular}

Analisis Pelaku Bisnis

Merupakan analisis yang menggambarkan siapa saja yang terlibat disetiap proses bisnis yang ada pada sistem. 
Tabel 2. Analisis Pelaku Bisnis

\begin{tabular}{lll}
\hline No & Proses & Pelaku \\
\hline 1 & Pemesanan & Customer dan customer service \\
\hline 2 & Produksi & Customer service dan bagian produksi \\
\hline 3 & Pembayaran & Bagian keuanagan dan customer \\
\hline
\end{tabular}

\section{Analisis Sistem Berjalan}

Analisis sistem berjalan adalah tahapan analisis yang bertujuan untuk memberikan gambaran secara rinci bagaimana proses bisnis yang terjadi pada sistem yang digunakan saat ini. Salah satu cara untuk menganalisis sistem berjalan yaitu dengan flowmap. Berikut flowmap analisis sistem berjalan Anambaleh Desain.

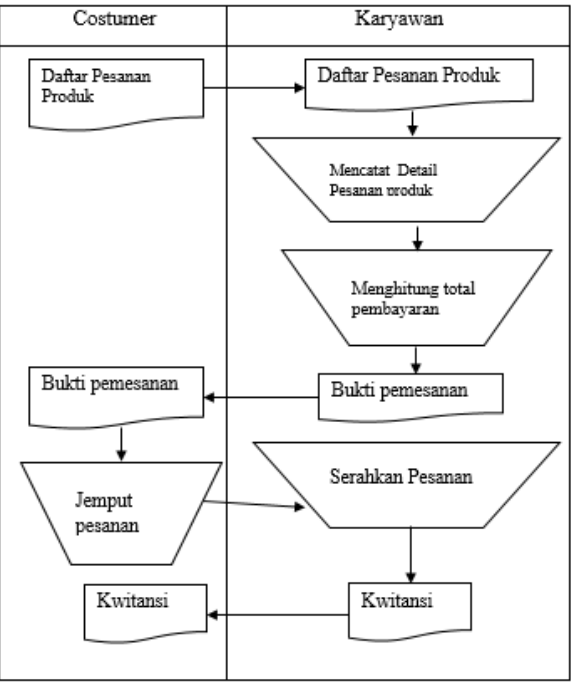

Gambar 2. Flowmap sistem berjalan Anambaleh Desain

Analisis Sistem yang Diusulkan

Analsis sistem yang diusulkan bertujuan untuk memberikan gambaran bagaimana sistem yang akan dibangun. Berikut ini adalah flowmap sistem yang diusulkan pada percetakan Anambaleh Desain

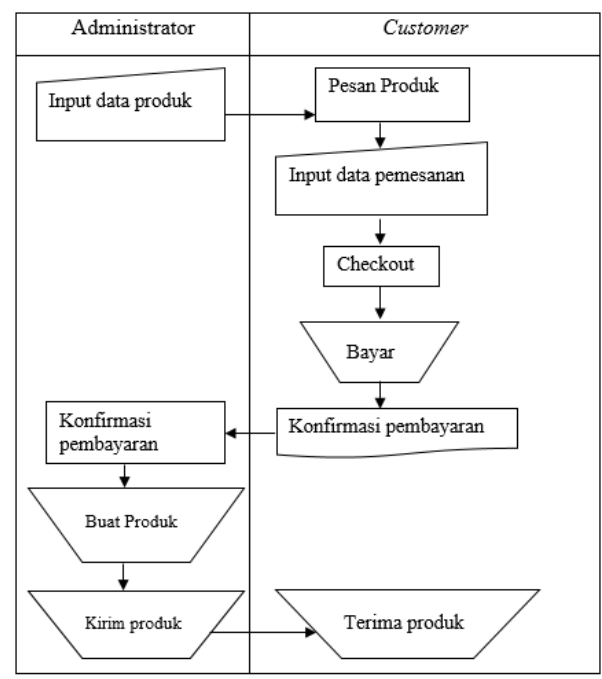

Gambar 3. Flowmap sistem Anambaleh Desain
Pada E-retail anambaleh desain yang berperan sebagai administrator adalah pemilik toko sebagai admin, dan karyawan. Admin dan karyawan bertugas untk mengelola produk dan transaksi pada sistem.

\section{Contex Diagram}

Contex diagram merupakan sebuah diagram yang bertujuan untuk memberi gambaran tentang ruang lingkup sebuah sistem. Berikut ini adalah contex diagram e-retail Anambaleh Desian.

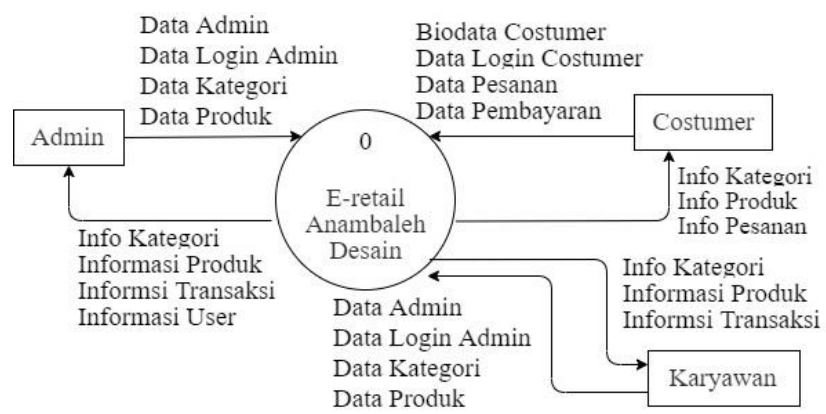

Gambar 4. Contex diagram e-retail Anambaleh Desain

Pada gambar contex diagram diatas terdapat tiga terminator yang memberikan input berupa data ke dalam sistem yang digmbarkan melalui panah dari terminator menuju sistem, serta mendapatkan output berupa informasi yang digambarkan dengan panah dari sistem menuju terminator.

\section{Use Case Diagram}

Use case diagram bertujan untuk menggambarkan kebutuhan fungsional suatu sistem serta menggambarkan interaksi-interaksi yang tejadi pada sistem.

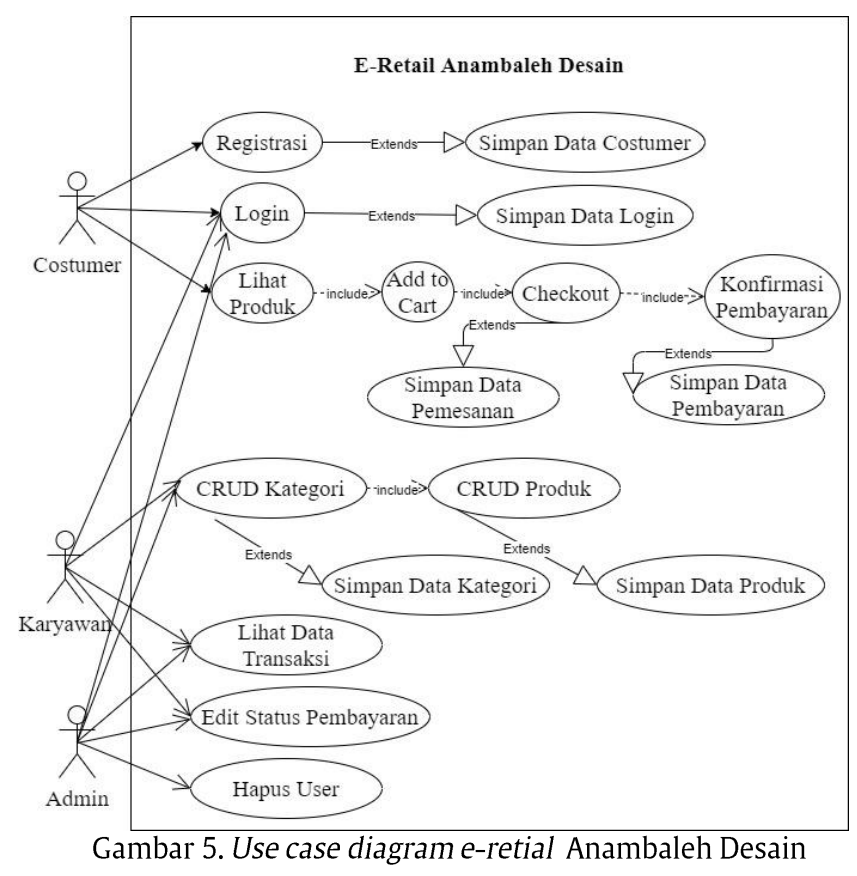


Pada gambar diatas panah include menunjukkan actor harus melakukan proses secara berurutan untuk melakukan sebuah aktivitas pada sistem. Panah extend menunjukkan kemana data akan disimpan. Usecase diagram terdiri dari tiga actor, yaitu admin, karyawan dan user, Admin Pada sistem ini adalah pemilik toko. Admin dan karyawan bertugas untuk mengelola produk, kategori dan order. Selain itu admin dapat menghapus data user. Sedangkan customer adalah user yang berbelanja pada sistem.

\section{Activity Diagram}

Bertujuan unutk memberikan gamabaran bagaimana aktivitas yang terjadi pada sistem, langkah-langkah dan proses kerja sebuah sistem dari awal sampai akhir [10].

Berikut ini adalah adalah activity diagram pada e-retail Anambaleh Desain.

\section{Activity Diagram Registrasi User}

Activiy ini menjelaskan proses registrasi user dari awal sampai akhir. Berikut ini adalah Activity Diagram registrasi customer pada e-retail Anambaleh desain :

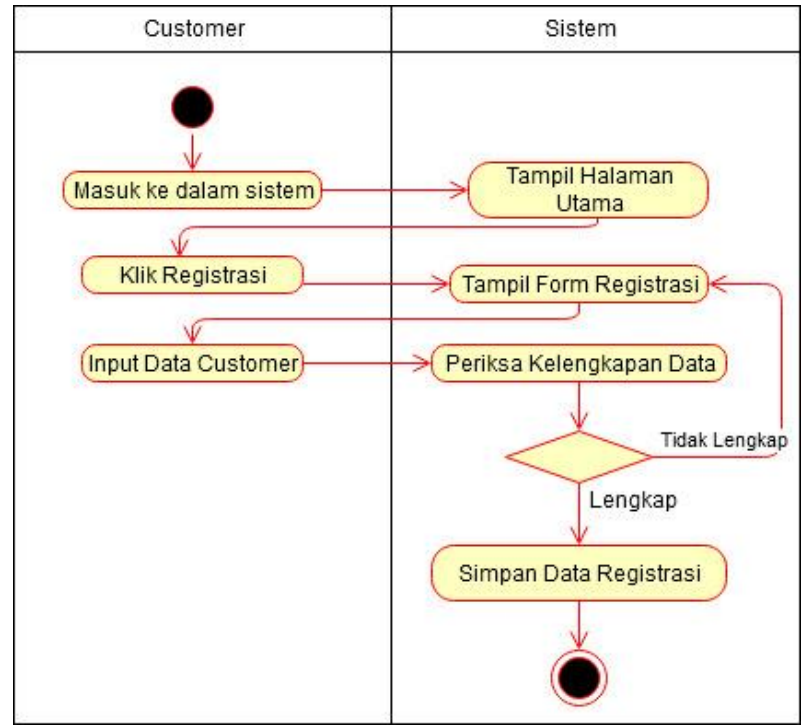

Gambar 6. Activity diagram registrasi user e-retial Anambaleh Desain

Gambar activity diagram registrasi menjelaskan proses registrasi pada sistem. Pada tahap ini user harus memasukkan data yang nantinya digunakan untuk login ke dalam sistem.

\section{Activity Diagram Login User}

Activity diagram login user menjelaskan tahapan user masuk ke dalam sistem.

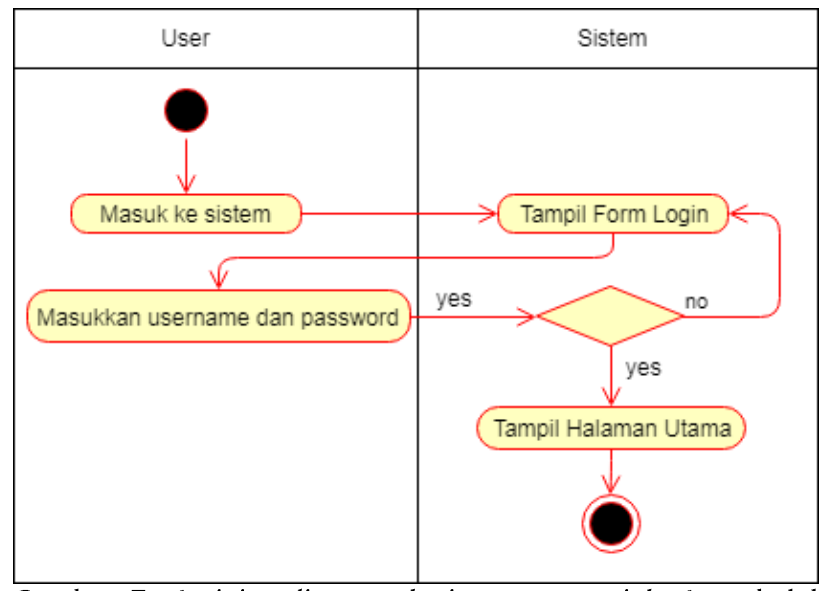

Gambar 7. Activity diagram login user e-retial Anambaleh Desain

Gambar activity diagram login menjelaskan proses login user ke dalam sistem. Dimana user harus memasukkan username atau email dan password yang telah didaftarkan pada tahap registrasi. Jika username dan password yang dimasukkan benar maka user akan masuk ke halaman utama.

\section{Activity Diagram Tambah Produk}

Activity diagram tambah produk menjelaskan proses karyawan menambahkan produk yang akan dijual.

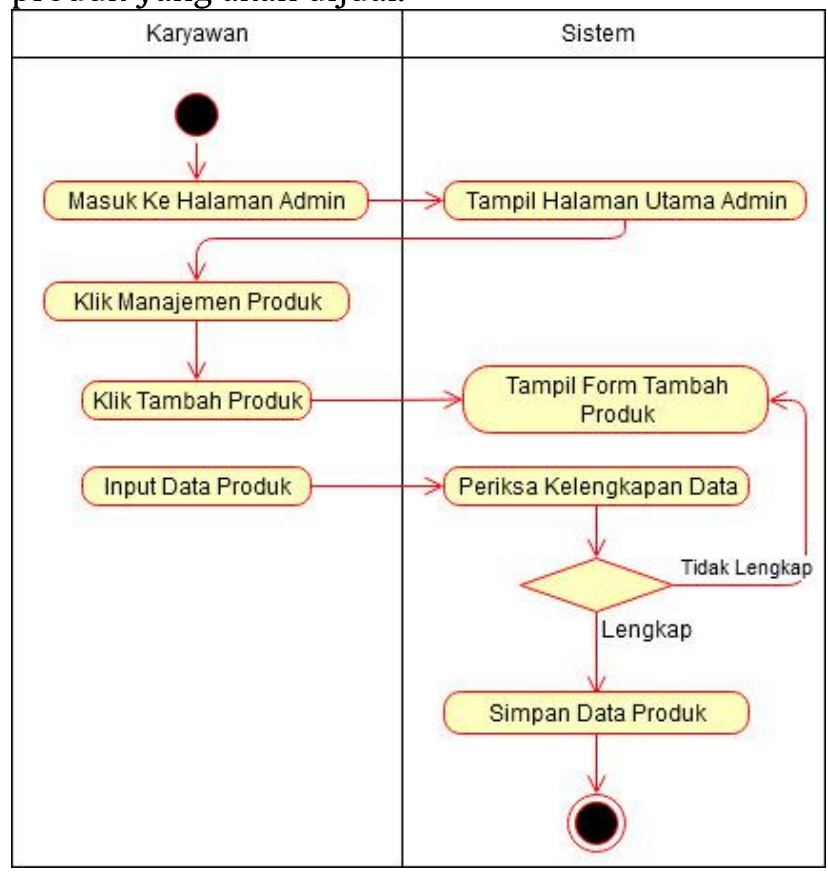

Gambar 8. Activity diagram tambah produk e-retial Anambaleh Desain

Gambar activity diagram tambah produk menjelaskan untuk menambahkan produk karyawan harus login terlebih dahulu. Selanjutnya karyawan dapat melakukan proses tambah produk. 


\section{Activity Diagram Pesan Produk}

Activity diagram pesan produk menggambarkan tentang tahap pemsanan produk.

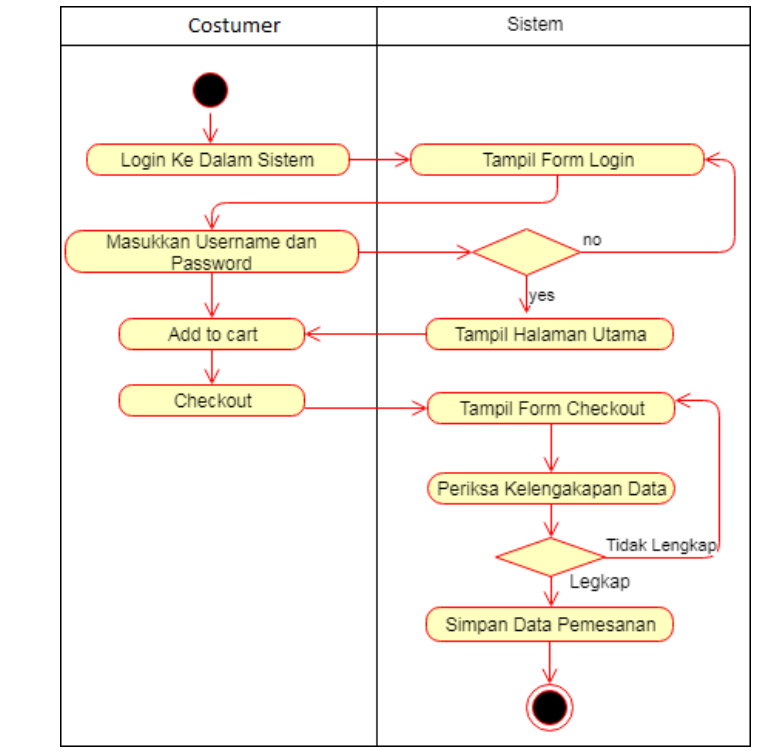

Gambar 9. Activity diagram pesan produk e-retial Anambaleh Desain

Activity diagram pesan produk menggambarkan proses customer memesan produk pada e-retail Anambaleh Desain. Alur proses pemesanan produk yaitu memilih produk untuk dimasukkan ke keranjang, dan mengisi form checkout.

\section{Activity Diagram Delete User}

Activity diagram delete user menggambarkan tentang tahap menghapus user.

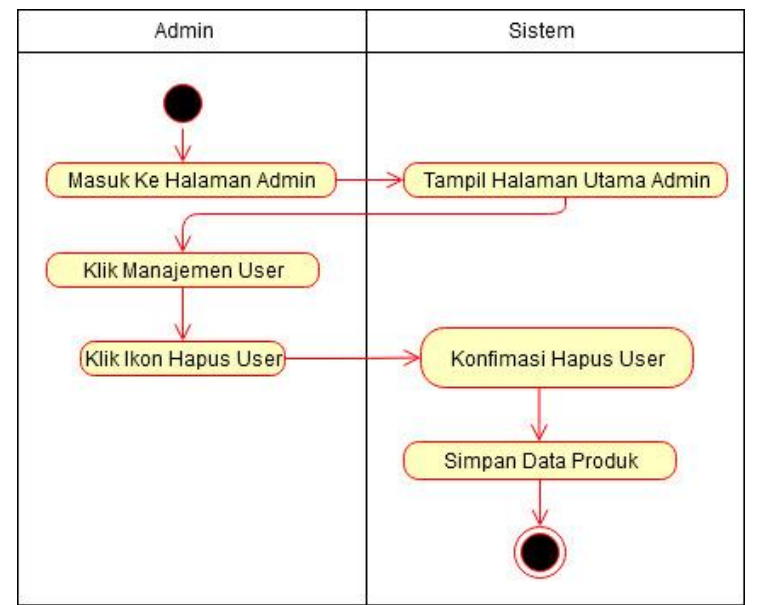

Gambar 10. Activity diagram delete user e-retial Anambaleh Desain

Activity diagram delete user menggambarkan proses admin menghapus user pada sistem, yaitu dengan cara masuk he halaman admin, lalu memilih manajemen user, dan menghapus user yang diinginkan.

\section{HASIL DAN PEMBAHASAN}

Berikut ini hasil dan pembahasan e-retail Anambaleh Desain.

\section{Registrasi}

Halaman ini ditampilkan pada user dengan role customer. Pada halaman ini, dilakukan proses input biodata customer agar bisa login ke dalam sistem. Pada halaman registrasi customer memasukkan data username, email, password, address dan phone. Semua form yang ditampilkan wajib diisi oleh customer. Jika proses registrasi berhasil, data akan disimpan ke dalam database, selanjutnya customer dapat melakukan proses login dengan email dan password yang telah didaftarkan. Berikut ini adalah form registrasi e-retail Anambaleh Desain.

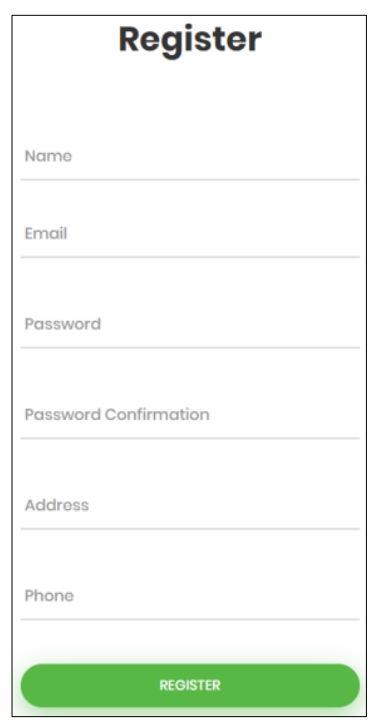

Gambar 11. Halaman registrasi e-retail Anambaleh Desain Login

Halaman ini digunakan oleh semua user untuk masuk ke dalam sistem.

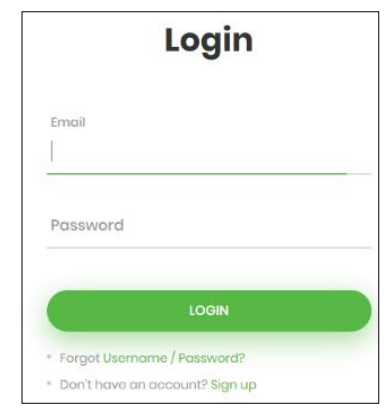

Gambar 12. Halaman login e-retail Anambaleh Desain

Pada proses ini, user memasukkan username dan password yang telah didaftarkan sebelumnya. Setelah proses login berhasil, user akan diarahkan ke 
halaman utama. Untuk user yang memiliki role admin maka akan diarahkan ke halaman admin, sedangkan user yang memiliki role customer akan masuk ke halaman homepage.

\section{Halaman Admin}

Halaman ini ditujukan untuk karyawan dan pemilik toko yang bertindak sebagai admin pada sistem. Pada halaman ini admin dapat mengelola data user, category, product, dan order.

\section{Manajemen Category}

Pada halaman ini, admin dapat melihat informasi kategori yang telah dimasukkan ke dalam sistem, menambah, mengedit, dan menghapus data kategori.

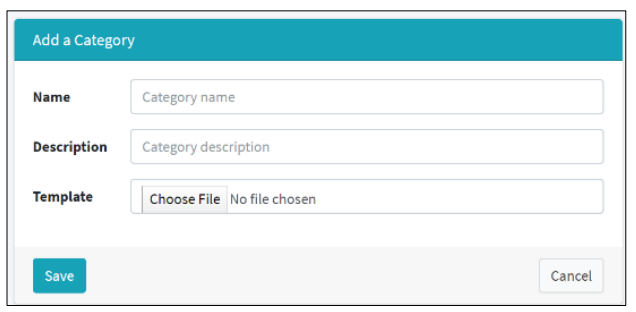

Gambar 13. Halaman add category e-retail Anambaleh Desain

Di halaman ini admin memasukkan data kategori yaitu nama kategori, deskripsi, dan template desain. Data yang berhasil disimpan akan ditampilkan pada halaman kategori. Berikut adalah tampilannya.

\begin{tabular}{|c|c|c|c|c|c|c|}
\hline \multicolumn{7}{|c|}{ Category List } \\
\hline \multirow[b]{2}{*}{$\#$} & \multirow[b]{2}{*}{ Name } & \multirow[b]{2}{*}{ Slug } & \multirow[b]{2}{*}{ Description } & \multirow[b]{2}{*}{ Template } & \multicolumn{2}{|c|}{ Add Category } \\
\hline & & & & & Actio & \\
\hline \# & Gantungan kunci & gantungan-kunci & Category for gantungan kunci & Template & $\square$ & 光 \\
\hline \# & Mug & mug & Category for mug & Template & $\square$ & 草 \\
\hline \# & Name Tag & name-tag & Category for name tag & Template & $\square$ & 五 \\
\hline \# & Pin & pin & Category for pin & Template & $\square$ & $\overline{\mathbf{E}}$ \\
\hline \# & Plakat & plakat & Category for plakat & Template & $\square$ & $\mathbf{E}$ \\
\hline \# & Selempang & selempang & Category for selempang & Template & $\square$ & $\boldsymbol{\square}$ \\
\hline \# & Undangan & undangan & Category for undnagan & Template & $\square$ & 口 \\
\hline
\end{tabular}

Gambar 14. Halaman category list e-retail Anambaleh Desain

Data kategori yang telah masuk ke dalam list kategori dapat diedit dan dihapus.

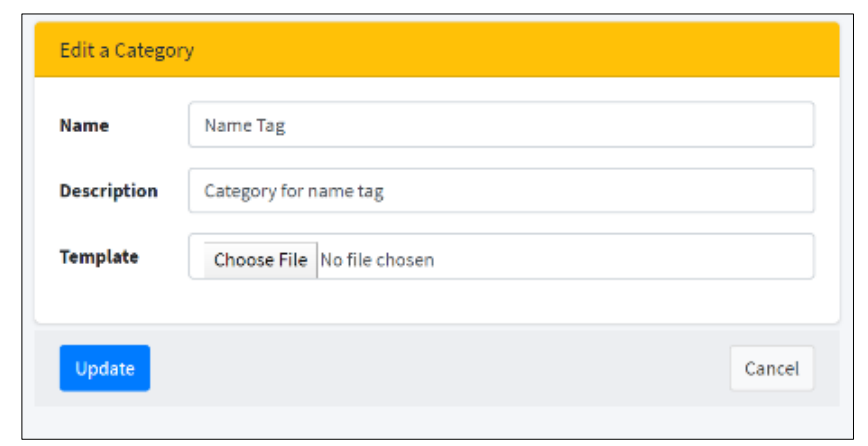

Gambar 15. Halaman edit category e-retail Anambaleh Desain
Pada form edit kategori ini ditampilkan data yang telah disimpan sebelumnya dengan tujuan agar user dapat mengetahui di bagian mana kesalahan yang akan diedit. Selain itu admin juga dapat menghapus kategori. Sebelum menghapus kategori, sistem akan menampilkan alert hapus kategori. Pada alert tersebut, user dapat memilih ok jika ingin menghapus kategori, atau memilih cancel untuk membatalkan. Berikut adalah tampilan konfirmasi hapus kategori. 


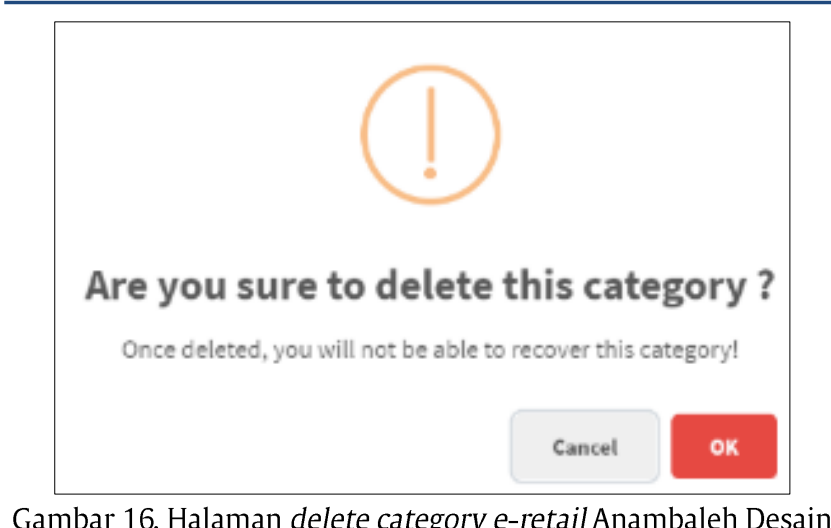

\section{Manajemen Product}

Halaman ini, sistem manampilkan informasi produk, menambah, mengedit, dan menghapus data produk. Berikut ini adalah tampilan tambah data produk.

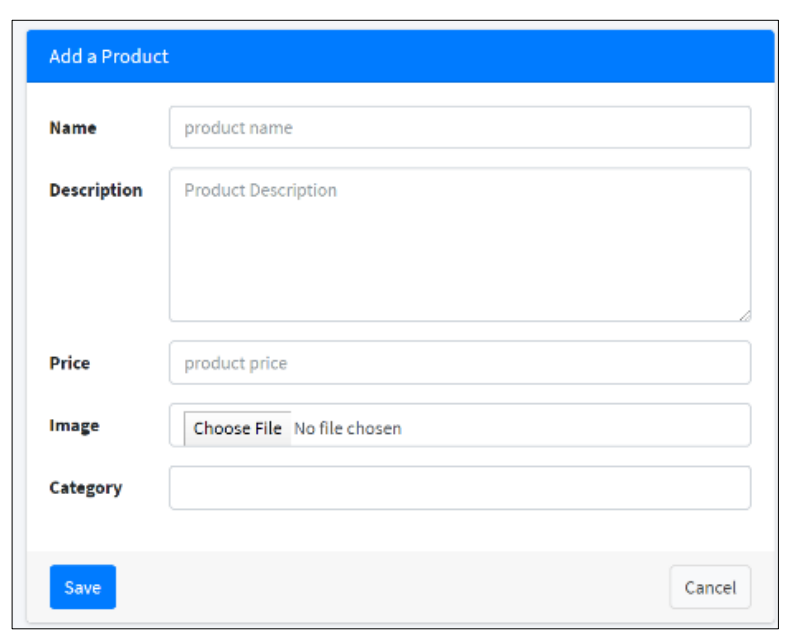

Gambar 17. Halaman add product e-retail Anambaleh Desain

Di halaman ini admin memasukkan data produk. Setelah data berhasil disimpan ke database. maka data tersebut akan ditampilkan pada halaman produk. Berikut adalah tampilanya. Data produk yang telah masuk ke dalam list product dapat diedit dan dihapus. Berikut adalah tampilan untuk mengedit produk.

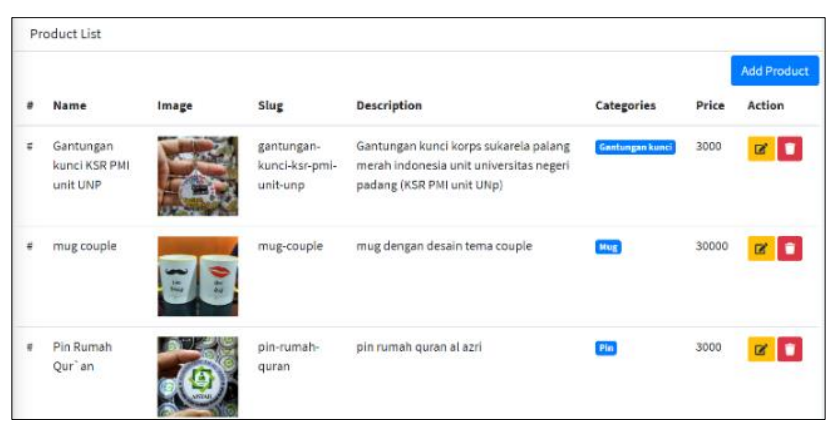

Gambar 18. Halaman list product e-retail Anambaleh Desain

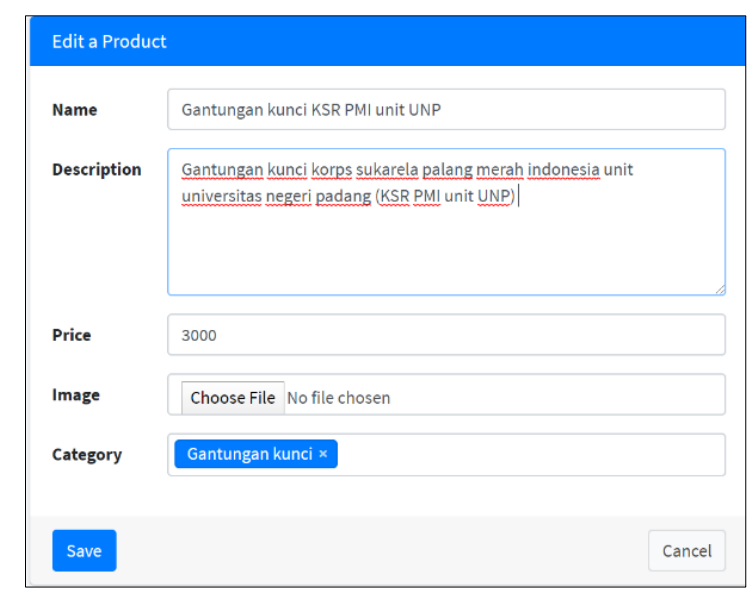

Gambar 19. Halaman edit product e-retail Anambaleh Desain

Pada form edit produk ini admin dapat mengedit data produk yang sebelumnya telah ditambahkan. Selain itu, admin juga dapat menghapus kategori. Untuk menghapus kategori, admin dapat memilih menu dengan ikon tempat sampah.

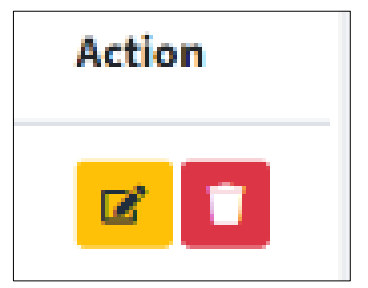

Gambar 20. Delete product e-retail Anambaleh Desain

Sebelum menghapus data produk, sistem akan menampilkan alert untuk konfirmasi.

\section{Manajemen User}

Pada halaman ini, admin dapat melihat data user yang telah terdaftar pada sistem.

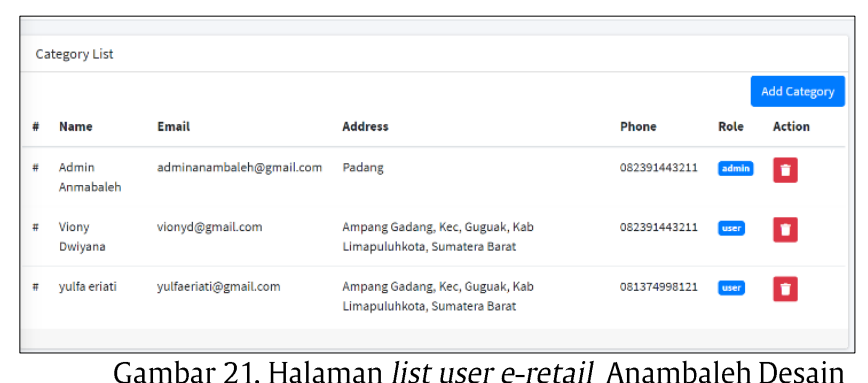

Gambar 21. Halaman list user e-retail Anambaleh Desain

Halaman ini menampilkan informasi berupa data user yang telah terdaftar. Pada Halaman ini pemilik toko dapat menghapus data user jika diperlukan.

\section{Manajemen Order}

Halaman ini menampilkan data order yang masuk ke dalam sistem. Berikut ini adalah tampilannya. 


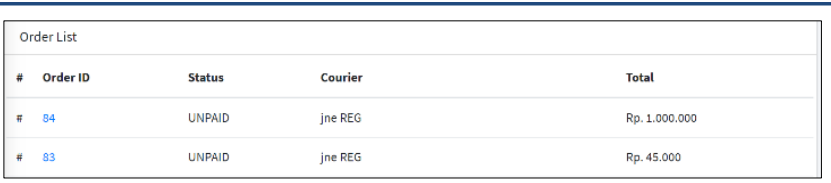

Gambar 22. Halaman order list e-retail Anambaleh Desain

Di halaman ini, admin dapat melihat data id order, status pembayaran, kurir dan total. Untuk melihat data order yang lebih rinci, admin dapat melihat detail order. Berikut ini adalah tampilan detail order.

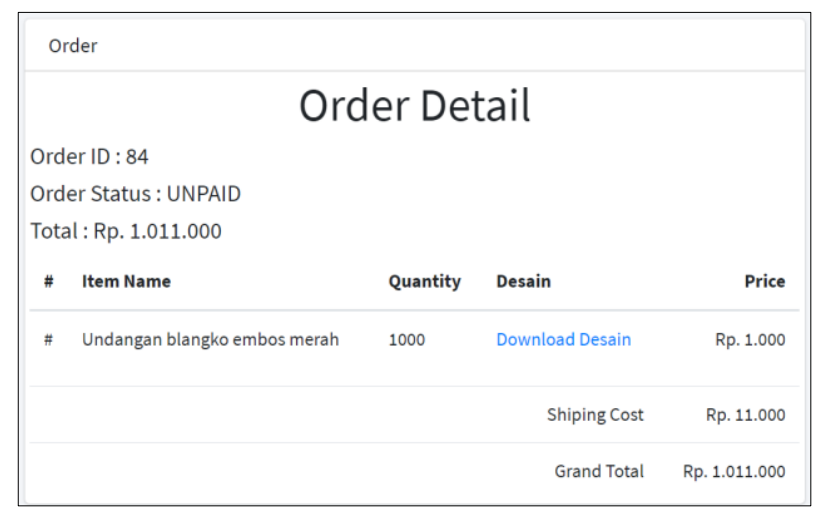

Gambar 23. Halaman detail order e-retail Anambaleh Desain

Pada halaman ini admin dapat melihat data order secara lebih rinci. Selain itu admin dapat mengunduh data desain yang diinginkan customer yang selanjutnya akan dijadikan pedoman pada proses produksi.

\section{Halaman Customer}

Halaman ini ditujukan untuk customer Anambaleh Desain. Pada halaman ini, customer dapat melakukan pemesanan. Tahap-tahap pemesanannya adalah sebagai berikut :

\section{Pilih Produk}

Customer dapat memilih produk yang ingin dipesan pada halaman homepage. Berikut ini adalah tampilan halaman homepage :

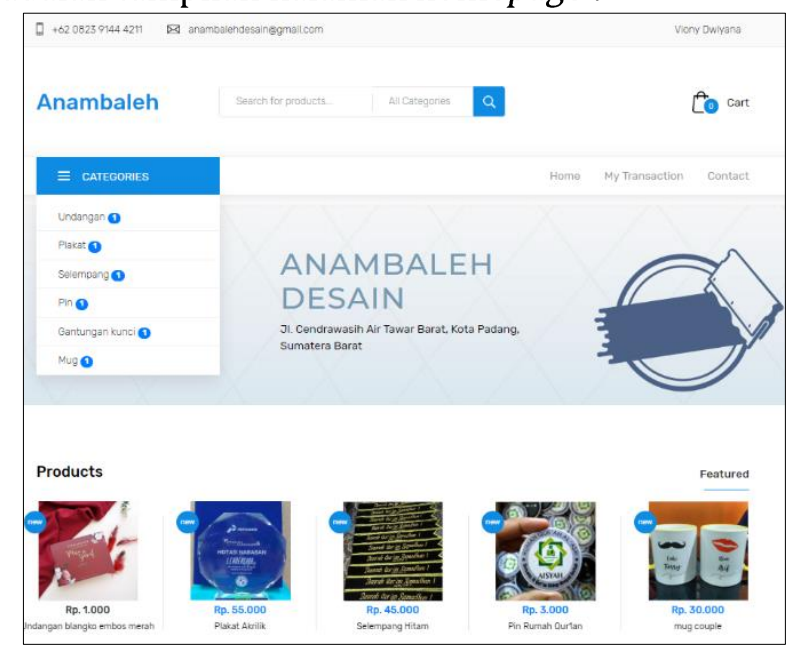

Gambar 24. Halaman homepage e-retail Anambaleh Desain
Pada halaman homepage, customer dapat memilih produk yang dinginkan. Di halaman ini ditampilkan gambar, nama, harga dan deskripsi produk sebagai bahan pertimngan untuk melakukan pemesanan. Selain itu pada halaman ini customer juga dapat melihat kategori-kategori produk pada e-retail Anambaleh Desain.

\section{Detail Pesanan}

Pada halaman ini, customer mengisi data pemesanan untuk produk yang dipilih. Pada tahap ini, customer mengisi data yag akan dimasukkan ke keranjang belanja. Selain itu, customer juga dapat melihat informasi tentang produk yang akan dibeli. Berikut ini merupakan tampilan untuk detail pemesanan pada halaman user e-retai Anamabaleh Desain :

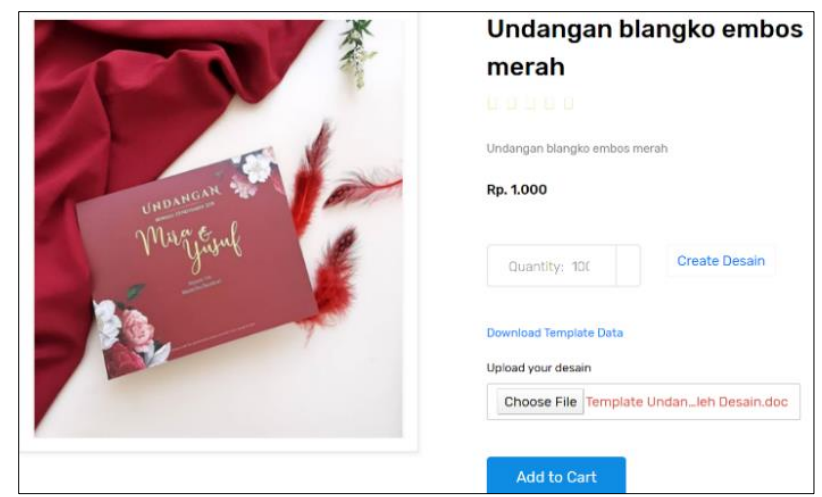

Gambar 25. Halaman detail pesanan untuk customer e-retail Anambaleh Desain

Di halaman ini, customer diminta untuk memasukkan jumlah produk yang dipesan. Selain itu, customer harus mengunggah data yang akan dimasukkan ke dalam produk nantinya. Pada bagian ini, customer dapat mengunggah desain yang dimiliki, atau mengunduh template untuk mengisi data yang diperlukan.

\section{Shopping Cart}

Shopping cart memberikan informasi tentang produk yang dipesan.

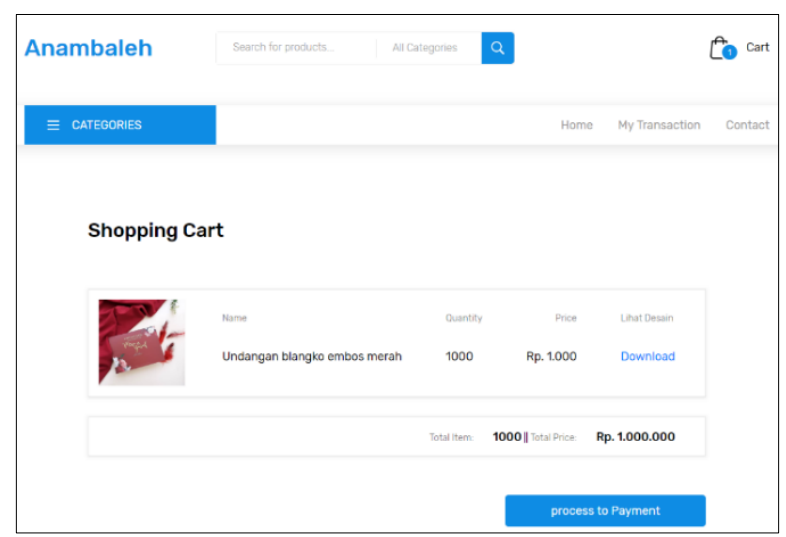

Gambar 26. Halaman shopping cart e-retail Anambaleh Desain 
Halaman ini berisi tentang informasi produk yang telah masuk ke keranjang customer. Pada halaman ini, customer dapat melihat data gambar, nama, jumlah, harga, desain, dan total harga produk yang dimasukkan ke keranjang. Setelah proses ini customer akan masuk ke halaman checkout.

\section{Checkout}

Pada halaman ini, customer mengisi form yang akan menjadi sumber data untuk pengiriman barang. Berikut ini adalah tampilan halaman checkout :

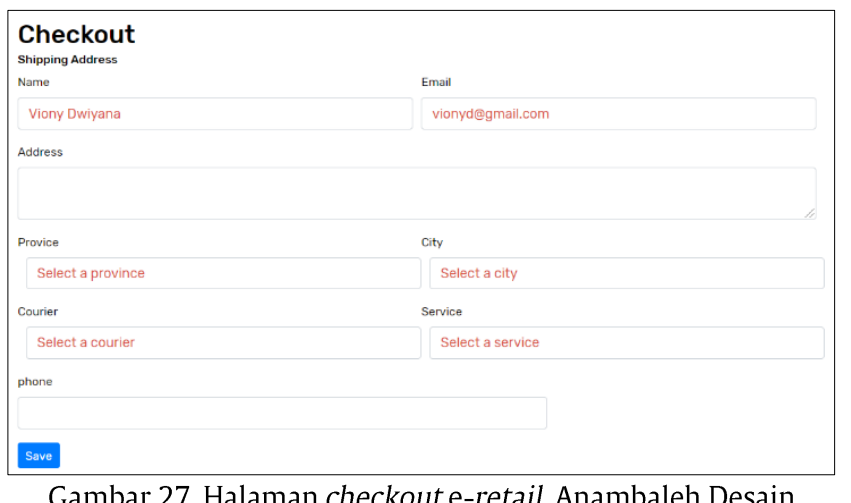

Di halaman checkout, user diminta untuk mengisi alamat, kota, provinsi, kurir, jenis servis, dan nomor handphone. Berdasarkan alamat yang dimasukkan, customer akan mendapatkan informasi ongkos kirim yang harus dibayar.

\section{Order Detail}

Pada halaman ini customer akan mendapatkan informasi tentang data pemesanan dan data bank tujuan untuk pembyaran.

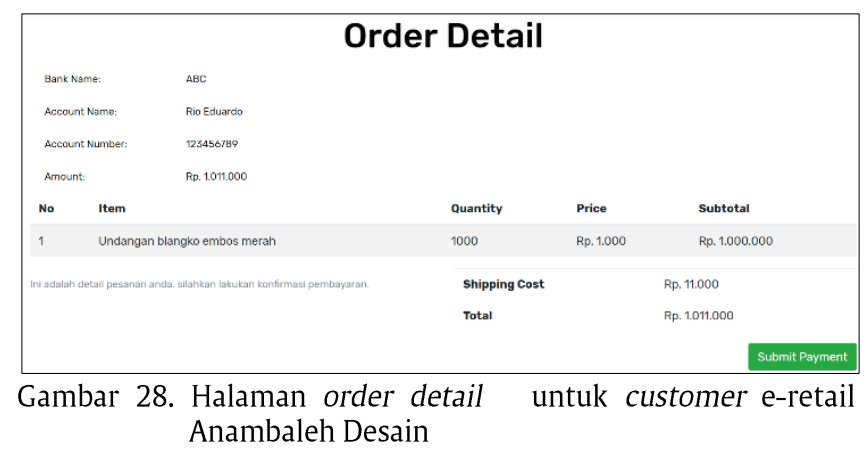

Berdasarkan informasi yang didapatkan oleh customer pada halaman order detail ini, selanjutnya customer dapat melakukan pembayaran.

\section{KESIMPULAN}

Kesimpulan percancangan e-retail Anambeleh Desain ini adalah sebagai berikut :

1. E-retail Anambaleh Desain dibuat dengan bahasa pemrograman PHP, dengan framework Laravel, serta menggunakan MySQL untuk database management system.

2. E-retail Anambaleh Desain merupakan media untuk memperluas pemasaran produk percetakan Anambaleh Desain.

3. E-retail Anambaleh Desain dapat mengelola transaksi dan pelayanan pada percetakan Anamabeleh Desian.

4. E-retail Anambaleh Desain adalah media untuk mendapatkan informasi tentang produk-produk Anambaleh Desain bagi customer.

5. E-retail Anambaleh Desain dapat menjadi media dalam mengolah dan berbagi data pada percetakan Anambaleh Desain.

\section{DAFTAR PUSTAKA}

[1] C. D. Lisa Harris, Marketing the E-business. 2002.

[2] Juniyati(Binus University), "E-Tailing," https://sis.binus.ac.id, 2018. [Online]. Available:

https://sis.binus.ac.id/2018/03/07/e-tailing/.

[3] D. Novaliendry, "Pengembangan Keterampilan Siswa Dibidang Desain Grafis Dan E - Commerce Dibidang Jasa Digital Printing," J. Teknol. Inf. dan Pendidik., vol. Vol. 12 , pp. 21-24, 2019.

[4] D. D. S. Ruli Erinton, Ridha Muldina Negara, "Analisis Performasi Framework Codeigniter Dan Laravel Menggunakan Web Server Apache," eProceedings Eng., 2017, doi: 10.1016/j.jcfm.2006.05.004.

[5] Achmad Yusron Arif, "Pengertian MySQL, Kelebihan Dan Kekurangan," 2019.

[6] Y. Hoster), "Pengertian MySQL, Fungsi, dan Cara Kerjanya," https://www.niagahoster.co.id. [Online]. Available: https://www.niagahoster.co.id/blog/mysqladalah/\#Pengertian_MySQL.

[7] R. Abdulloh, 7 in 1 Pemrograman Web Tingkat Lanjut. 2018.

[8] "MVC," https://id.wikipedia.org/wiki/MVC. Wikipedia, Ensiklopedia Bebas, 2017.

[9] J. Syahreza, "Pengertian PHP \& MySQL," 
http://tip.ppj.unp.ac.id

Membangun Aplikasi Web dengan Metode OOP. 2015.

[10] A. R. Pratama, "Belajar UML - Activity Diagram," codepolitan, 2019. [Online].

Available:

https://www.codepolitan.com/mengenaluml-contoh-uml-diagram-model-activitydiagram. 